\title{
Landscape parameters explain the distribution and abundance of Episyrphus balteatus (Diptera: Syrphidae)
}

\author{
JeAn-Pierre SARThOU ${ }^{1}$, AnNie OUIN ${ }^{1}$, Florent ARRIGNON ${ }^{1}$, GaËl BARREAU $^{2}$ and Bernard BOUYJOU ${ }^{1}$ \\ ${ }^{1}$ Ecole Nationale Supérieure Agronomique de Toulouse, UMR Dynafor, BP 107, F-31326 Auzeville-Tolosane, France; \\ e-mail: sarthou@ensat.fr \\ ${ }^{2} 12$, rue Claude Bizot, F-33170 Gradignan, France
}

Key words. Syrphidae, Episyrphus balteatus, distribution, abundance, seasons, forest edges, landscape

\begin{abstract}
We studied the importance of forest structure (shape, edge length and orientation) and the crop mosaic (percentage of crops in the total land cover, within 100 and $2000 \mathrm{~m}$ from the forests) to the dynamics of an aphidophagous hoverfly Episyrphus balteatus. Adults were collected by Malaise traps located within and on the south- and north-facing edges of 54 forests. In winter, $E$. balteatus was only found on south-facing edges because of the greater insolation and temperature. In summer, it was more abundant on north-facing edges because of the abundant presence of flowers. In spring, more adults were found on long and south-facing edges than on northern edges. The presence of shrubs within $2000 \mathrm{~m}$ also positively affected abundance. In autumn, abundance was positively associated with length of the north-facing edge and forest shape. Emergence traps revealed that in southern France, E. balteatus may overwinter in the larval or puparial stage in forest edges. Overwintering was earlier reported only in adults. Landscape structure, length of forest edges and probably presence of shrub fallows, influence abundance of Episyrphus balteatus.
\end{abstract}

\section{INTRODUCTION}

Because most of the natural enemies of crop pests do not carry out their complete life cycle in cultivated fields, many studies focus on the important role of uncultivated elements of the farmed landscape, such as hedges, field margins, "beetle banks" and fallows, in increasing their populations and in improving their efficiency (Russel, 1989; Landis et al., 2000; Gurr et al., 2004) as control agents. For example, in a structurally complex landscape, still characterised by several tens of metres of hedges per hectare, parasitisation of rape pollen beetle (Meligethes aeneus) larvae has been reported to be higher and the damage of this pest on oilseed rape (Brassica napus) crop lower, than in a structurally more simple landscape with larger fields and a high percentage of agricultural use (Thies \& Tscharntke, 1999). Marino \& Landis (1996) found similar results about parasitisation of armyworm in maize fields.

At the landscape scale, patch isolation is often predicted to have a negative effect on population density and species richness, because many isolated patches have lower immigration and emigration rates, thus reducing possibilities of recolonisation and rescue (McArthur \& Wilson, 1967). Consequently, some studies have focussed on the significance of degree of isolation on biological control in agroecosystems (Tscharntke \& Kruess, 1999). Patch isolation may have a positive effect on population density for prey or host species which are controlled by enemies. Indeed, it may disrupt the enemy's ability to detect the prey (Kareiva, 1987) as Kruess \& Tscharntke (1994) showed with isolated fields of bush vetch (Vicia sepium) which were less colonised by parasitoids of seed feeders.

The features that are most often cited as positively influencing natural enemies in non-crop elements of the farmed landscape are area, floristic composition and also the shape of the largest features (Nentwig, 1988; Molthan, 1990; Thomas et al., 1992).

In some landscapes characterised by forest fragments surrounded by crop mosaic, forests and their edges could play the role of natural enemy reservoirs for at least one phase of the life cycle of beneficial arthropods. If so, the issue would be how forests and their edges in a rural landscape should be distributed, shaped and managed in such a way as to favour natural enemies at both local and regional landscape levels.

In the present study we analyse the effect of local and regional landscape context, and forest fragment features, on the distribution and abundance of an aphidophagous beneficial species: Episyrphus balteatus (De Geer, 1776) (Diptera: Syrphidae). The larva of this species is one of the most efficient predators of crop aphids (Ankersmit et al., 1986; Poehling, 1988), and the adults feed on flowers both for energy and amino acids, needed particularly by females for oocyte maturation (Schneider, 1948). E. balteatus is the most studied species among Syrphidae by virtue of its efficiency as a predator and also its abundance in most terrestrial habitats. This species is also known to overwinter as fertilised females in southern parts of Europe (Lyon, 1967), but also by migrating southwards in the autumn throughout most of Europe (Aubert et al., 1976).

It is well known that the sooner aphidophagous beneficials establish in crop aphid colonies, the greater the chance is of keeping pest populations below damaging levels (Tenhumberg \& Poehling, 1995); this fact has also been demonstrated for syrphids (Honěk, 1983; Tenhumberg \& Poehling, 1995; Corbett, 1998). Thus in southern European regions where E. balteatus overwinters, it is 
worthwhile to try to improve its overwintering conditions, in order that it will be present in aphid colonies as early and as abundantly as possible in the spring.

A previous study dealing with syrphid diversity in 54 forests in relation to geometric features of forests and landscape (Ouin et al., in press), encountered large numbers of adult $E$. balteatus (almost $20 \%$ of the more than 4900 syrphids collected), unevenly distributed among the forests. We know that (i) forests and their edges are some of the most stable structures in rural landscapes, (ii) $E$. balteatus is a pollen and nectar-feeding insect in the adult stage and probably overwinters as adult females at least in sheltered places, (iii) in different seasons, edges should thus be visited at different frequencies, dependent upon their particular characteristics, (iv) E. balteatus is almost ubiquitous (Speight, 2003) and mainly breeds in open habitats (including forest edges) rather than within forest habitats (Rojo et al., 2003), and lastly (v) in spring and autumn, forest interiors (which are not optimal habitats for the breeding of this species: Speight et al., 2003) can thus be supposed to act as filters and to be visited only by occasional foraging individuals. Given these, we test here the following hypotheses:

(1) E. balteatus distribution and abundance in forests depend upon both local and regional landscape parameters (peculiar to the forest and its surrounding crop mosaic, respectively), which vary in their influence according to the season; this hypothesis will subsequently be referred to as the "Local and wide landscape parameters hypothesis".

(2) Forest edges, south- as well as north-facing, and flowers in their vicinity, act as factors determining E. balteatus distribution and abundance, while forest interiors have no significative effect. Indeed, we assume that, in our study region, south- and north-facing edges act as winter and summer shelters, respectively (Sarthou, 1996); this hypothesis is subsequently referred to here as the "Edge-orientation and flower hypothesis".

(3) E. balteatus overwinters also at a pre-imaginal stage, at least along forest edges, from which it spreads through the landscape in spring; this is referred to as the "Pre-imaginal overwintering stage hypothesis".

\section{STUDY SITES AND METHODS}

\section{Study region}

The study region lies between the Garonne and Gers rivers in south-western France (ca. lat: $43^{\circ}$, long: $1^{\circ}$ ). This hilly region (200-400 m alt.) is located within a sub-Atlantic climate zone subject to both Mediterranean and montane influences. Forest covers $15 \%$ of the area, composed of multiple small, privatelyowned forest fragments (Balent \& Courtiade, 1992). The forests are maintained primarily for firewood production (for consumption and for sale in local markets) in a coppice silvicultural system, with a felling rotation ranging from 15 to 40 years (Guyon et al., 1996). Farmers maintain the edges by cutting scrub and sometimes trees, so that the agricultural fields are not invaded.

Local and wide landscape parameters hypothesis

54 forests were chosen according to their surface area (from 0.5 to $171 \mathrm{ha}$ ) and the crop mosaic between and around them.
Edge orientation and flower hypothesis

Ten other forests were chosen according to their squat shape, their surface area (from 1,5 to 4 ha) and their northerly orientation and topographical location (with a south-facing edge rising on a hilltop or slope, and a north-facing one stretching into a basin bottom or close to it). These features were all exhibited by the greater part of the forests in this region.

Pre-imaginal overwintering stage hypothesis

Five of the ten forests described above were chosen so that they covered the same general geographical area in the landscape (from north towards south, and from east towards west) as the larger set of ten.

\section{Trapping methods}

Local and wide landscape parameters hypothesis

We adjusted sampling intensity to the forest fragment area in an asymptotic manner: one trap for each 5 ha unit up to 15 ha, one trap more for each 10 ha up to 95 ha, and then one trap more for each 25 ha interval, so that the largest forest (171 ha) had 15 sampling stations. Traps were installed in a total of 54 forests and samples were collected from 10th May to 14th June 2000 (hereafter called the spring) and from 13th September to 19th October 2000 (hereafter called the autumn). The traps were set up at sparsely-vegetated and quite well-lit locations. The traps used were interception Malaise traps, composed of black (non-attractive) vertical walls and roof (Marris House Nets model). The sample bottles, part-filled with $70 \%$ ethyl alcohol, were replaced every fortnight.

\section{Edge orientation and flower hypothesis}

Each of the ten forests was fitted out with one trap on its south-facing $\left(180^{\circ} \pm 40^{\circ}\right)$ and one on its north-facing edge $\left(0^{\circ} \pm\right.$ $\left.40^{\circ}\right)$; a third was placed in its centre. All of the ten forest centres are quite densely vegetated and less well-lit than the edges. A total of 30 traps were installed from the beginning of March 2003 to the beginning of March 2004, and operated continuously. These traps were of the same Malaise-trap model, and the sample bottles were managed in the same way.

\section{Pre-imaginal overwintering stage hypothesis}

Each of the five forests was fitted out with one emergence trap on the south-facing edge and another on the north-facing edge. A total of 10 traps were in operation from the beginning of February 2004 to the end of June 2004 and the sample bottles were checked every two weeks until the beginning of May, then replaced every two weeks. The traps used were large emergence traps, based on the Marris House Malaise trap model, each enclosing a surface area of approximately $4 \mathrm{~m}^{2}$ of varied spontaneous low vegetation at the foot of trees. Given their intended purpose, care had to be taken to ensure these traps were effectively pegged to the ground, thus preventing flying syrphids from entering them. The emergence-trap sample bottles were also part-filled with $70 \%$ ethyl alcohol.

\section{Parameter recording}

\section{Local and wide landscape parameters hypothesis}

Four SpotView images (pixel resolution: $20 \mathrm{~m}$ ) were used to map the study region, mainly to characterise the agricultural matrix. Images in Multiband mode were taken on April 2001, July 2001, October 2001 and January 2002. Land-cover analysis was based on field evaluation from which eight land-cover categories were established: forests, winter and summer crops, temporary and permanent grasslands (including indistinguishable Common Agricultural Policy fallows), shrub fallows, water and urban areas. Both forest and crop-mosaic parameters were taken (Table 1), as follows: 
TABLE 1. Explanatory variables used in the PLS models.

\begin{tabular}{ll}
\hline & Meaning \\
\hline EL & Surface area of forest fragment \\
LNE & Edge length of forest fragment \\
LSE & Length of north-facing edge \\
S/EL & Length of south-facing edge \\
Grass-100 & Shape: given by the ratio surface area / edge length \\
Wint.crop-100 & Proportion of the land cover in grassland in a buffer zone of $100 \mathrm{~m}$ around the forest. \\
Shrub fal-100 & Proportion of the land cover in winter crop (wheat, oat) in a buffer zone of $100 \mathrm{~m}$ around the forest. \\
Grass-2000 & Proportion of the land cover in shrub fallows in a buffer zone of $100 \mathrm{~m}$ around the forest. \\
Wint.crop-2000 & Proportion of the land cover in grassland in a buffer zone of $2000 \mathrm{~m}$ around the forest. \\
Shrub fal-2000 & Proportion of the land cover in winter crop (wheat, oat) in a buffer zone of $2000 \mathrm{~m}$ around the forest. \\
\hline
\end{tabular}

- five measures of forest-fragment geometry (local-level parameters): surface area (S), edge length (EL), length of southfacing edge (LSE), length of north-facing edge (LNE), ratio $\mathrm{S} / \mathrm{EL}$ (this ratio indicates the forest-fragment shape);

- proportions of three land-cover types within two buffer zones (radii of $100 \mathrm{~m}$ and $2000 \mathrm{~m}$ ) around each forest (widelevel parameters): winter crops (essentially winter wheat), grasslands (temporary and permanent grasslands plus indistinguishable CAP fallows) and shrub fallows.

None of the forest habitat structure has been represented because all the forests were essentially overmature and mature Quercus pubescens populations (CORINE code 41.7) with a few Q. petraea, Carpinus betulus, Castanea sativa, Fagus sylvatica or Fraxinus excelsior, and with vague sparse zones where the traps were set up. Thus all the forests were equal to each other from the habitat point of view, but above all on the other hand were not very appropriate for the breeding of $E$. balteatus (Speight et al., 2003).

Edge orientation and flower hypothesis

Flower diversity was surveyed every fortnight, within $25 \mathrm{~m}$ along the forest edge on both sides of the trap (so within $50 \mathrm{~m}$ in length) and in the adjacent agricultural field within a semicircle of $25 \mathrm{~m}$ radius around each trap for the 20 traps in edges, and within a radius of $25 \mathrm{~m}$ around each trap for the 10 traps in forest centres. Temperature was recorded every $2 \mathrm{~h}$ on two south-facing edges and two north-facing ones, using HOBO 08 automatic recording probes (Prosensor SA-F).

\section{Data analysis}

Edge orientation and flower hypothesis

Flower data have been summed within each whole season for each trap, thus giving an overall better correspondence between Malaise traps which reveal E. balteatus abundance of a previous fortnight, and flower diversity which is an instantaneous reading. In this way, Edge Flowers correspond to the sum of flowers recorded along the forest edge, on both sides of traps, for all the dates comprising one sampling season. Field Flowers similarly correspond to the sum of flowers recorded in the field around traps for all the dates comprising one sampling season. Total Flowers is the sum of the two preceding variables for all the dates comprising one sampling season. E. balteatus Abundance is the sum of $E$. balteatus collected in a given trap for all the dates comprising one sampling season. The Mean Temperature is the mean of the day mean temperature.

\section{Statistical analysis}

Local and wide landscape parameters hypothesis

We used Partial Least Squares (PLS) regression to evaluate the importance of local and wide landscape parameters as determinants of E. balteatus adult abundance. PLS is a useful calibration technique when explanatory variables are correlated (Naes \& Martens, 1989), which is often the case with landscape data such as ours, but also when there is more than one response variable and missing data (Tenenhaus, 1998). This method consists of building latent variables (components) as a linear combination of explanatory variables that may themselves be correlated. It ensures orthogonality of components which are then regressed against the response variable. Model validity is assessed by three main indices: $\mathrm{R}^{2} \mathrm{X}$, the proportion of variance in the matrix of predictor variables that is used in the model, $\mathrm{R}^{2} \mathrm{Y}$, the proportion of variance in the response variable that is explained by the model and $\mathrm{Q}^{2}$ the proportion of variance in the response variable that can be predicted by the model. A model is considered significant when $\mathrm{Q}^{2}>0.097$ (Tenenhaus, 1998).

The relative influence of each explanatory variable may be estimated using the variable importance parameter (VIP), which is the sum of the variable's influence over all model dimensions divided by the total explained variation by the model. One can compare the VIP of one variable to the others. Variables with VIP $\geq 1$ are the most relevant and significant for explaining the response variable. Between 0.9 and 1 , variables can be considered as sub-significant. Since explanatory and response variables were standardised, coefficients of this equation may be interpreted as the influence of particular explanatory variable on the response variable. PLS analyses were done with the software SIMCA-P for Windows (Friden et al., 1994).

One model was tested for the abundance of each sex, and both sexes together, for each season. Thus six models were established with one dependent variable and eleven explanatory variables.

\section{Edge orientation and flower hypothesis}

Differences between samples were calculated using the Mann-Whitney test because of non-normality of data. This test allows a comparison between two samples according to their median and mean rank. Only $\mathrm{p}<0.05$ values were interpreted. Spearman rank correlations were calculated, and only correlations with a $p<0.05$ significance were interpreted. The significance of the difference in the mean daily temperature between south- and north-facing edges was tested for each of the two forests fitted out with probes, using the paired Wilcoxon test (temperatures being paired by days). These statistical analysis were conducted with Statistica 5.5 software (StatSoft, Inc., NL). 
TABLE 2. Summary of the PLS models fitted to E. balteatus abundance in woods. $\mathrm{R}^{2} \mathrm{X}$, the proportion of the variance in the matrix of predictor variables used in the model; $R^{2} Y$, the proportion of the variance in the response variable explained by the model; and $\mathrm{Q}^{2}$, the proportion of the variance in the response variable that can be predicted by the model (predictive power of the model).

\begin{tabular}{lcccc}
\hline Season & $\mathrm{Sex}$ & $\mathrm{R}^{2} \mathrm{X}$ & $\mathrm{R}^{2} \mathrm{Y}$ & $\mathrm{Q}^{2}$ \\
\hline \multirow{4}{*}{ spring } & $\mathrm{M}+\mathrm{F}$ & 0.30 & 0.46 & 0.33 \\
& $\mathrm{M}$ & 0.30 & 0.42 & 0.27 \\
& $\mathrm{~F}$ & 0.29 & 0.44 & 0.32 \\
\hline \multirow{3}{*}{ autumn } & $\mathrm{M}+\mathrm{F}$ & 0.29 & 0.48 & 0.32 \\
& $\mathrm{M}$ & & no model & \\
& $\mathrm{F}$ & 0.29 & 0.47 & 0.32 \\
\hline
\end{tabular}

\section{RESULTS}

\section{Local and wide landscape parameters hypothesis}

A total of 881 individuals (362 males and 519 females) of E. balteatus were captured: 783 in spring and 98 in autumn. While the abundance of males in autumn could not be related to any explanatory variable in a PLS model, all other models were significant with a $\mathrm{Q}^{2}$ higher than 0.097 (Table 2). From $42 \%$ to $48 \%$ of E. balteatus abundance variance was explained by the five models. More than $30 \%$ of the variation in E. balteatus abundance in forests could be predicted by the models.

In spring (Table 3), except for the model for females, four out of the five local parameters of forest-fragment geometry (i.e. surface area, edge length, length of southfacing edge, and the ratio of surface area to edge length) were the factors most positively and significantly influencing E. balteatus distribution and abundance. For females in spring, the factor with the most positive and significant influence was a landscape parameter, shrub fallows in a buffer of $2000 \mathrm{~m}$. This latter parameter also positively and significantly influenced the abundance of both sexes and males in spring, marginally less important

TABLE 3. Relation between landscape parameters (see Table 1 for meaning of abbreviations) and E. balteatus adult abundance in spring and autumn. Coefficients are given for each variable in each model; bold coefficients indicate VIP $>1$; bold and italic coefficients indicate $0.9<$ VIP $<1$.

\begin{tabular}{cccccccc}
\hline & \multicolumn{3}{c}{ Spring } & & \multicolumn{2}{c}{ Autumn } \\
\cline { 2 - 3 } \cline { 7 - 8 } & both sexes & males & females & & sexes & females \\
\hline SL & $\mathbf{0 . 1 6}$ & $\mathbf{0 . 1 5}$ & $\mathbf{0 . 2 1}$ & & $\mathbf{0 . 1 9}$ & $\mathbf{0 . 1 8}$ \\
LSE & $\mathbf{0 . 1 4}$ & $\mathbf{0 . 1 3}$ & $\mathbf{0 . 1 7}$ & & $\mathbf{0 . 1 5}$ & $\mathbf{0 . 1 5}$ \\
S/P & $\mathbf{0 . 1 2}$ & $\mathbf{0 . 1 2}$ & $\mathbf{0 . 1 4}$ & & $\mathbf{0 . 1 2}$ & $\mathbf{0 . 1 2}$ \\
LNE & 0.075 & 0.073 & $\mathbf{- 0 . 0 9 3}$ & & $\mathbf{0 . 0 9 5}$ & $\mathbf{0 . 1}$ \\
Grass.-100 & -0.047 & -0.042 & -0.05 & & -0.011 & -0.0041 \\
Wint.crop-100 & 0.003 & 0.011 & 0.16 & & 0.0051 & 0.0037 \\
Shrub fal.-100 & -0.007 & -0.002 & $\mathbf{- 0 . 2 4}$ & & -0.013 & -0.0096 \\
Grass.-2000 & $\mathbf{- 0 . 0 1}$ & $-\mathbf{0 . 0 1}$ & $\mathbf{- 0 . 1 5}$ & & -0.063 & -0.055 \\
Wint.crop-2000 & 0.029 & 0.0082 & 0.13 & & 0.022 & 0.016 \\
Shrub fal.-2000 & $\mathbf{0 . 1 1}$ & $\mathbf{0 . 1 0 3}$ & $\mathbf{0 . 2 2}$ & & 0.041 & 0.041 \\
\hline
\end{tabular}

than the forest-fragment geometry parameters. For females in spring again, shrub fallows in a $100 \mathrm{~m}$ buffer and the length of north-facing edges had a negative and significant influence on their abundance. Grasslands in a buffer of $2000 \mathrm{~m}$ acted negatively and very weakly but significantly, to explain abundance in spring for both sexes together and males, and a non-significant higher contribution for females.

In autumn (Table 3) the only significant variables (for females only, since there is no significant model for males) were four out of five forest-fragment geometry parameters. The fifth, i.e. the length of north-facing edge, had a sub-significant positive influence.

\section{Edge orientation and flower hypothesis}

Episyrphus balteatus numbers varied and were differently distributed along the forest edges, while they were very low in the forest centres (Fig. 1). In spring, E. balteatus abundance was not significantly different between north and south edges $(\mathrm{p}=0.26)$, while in summer it was

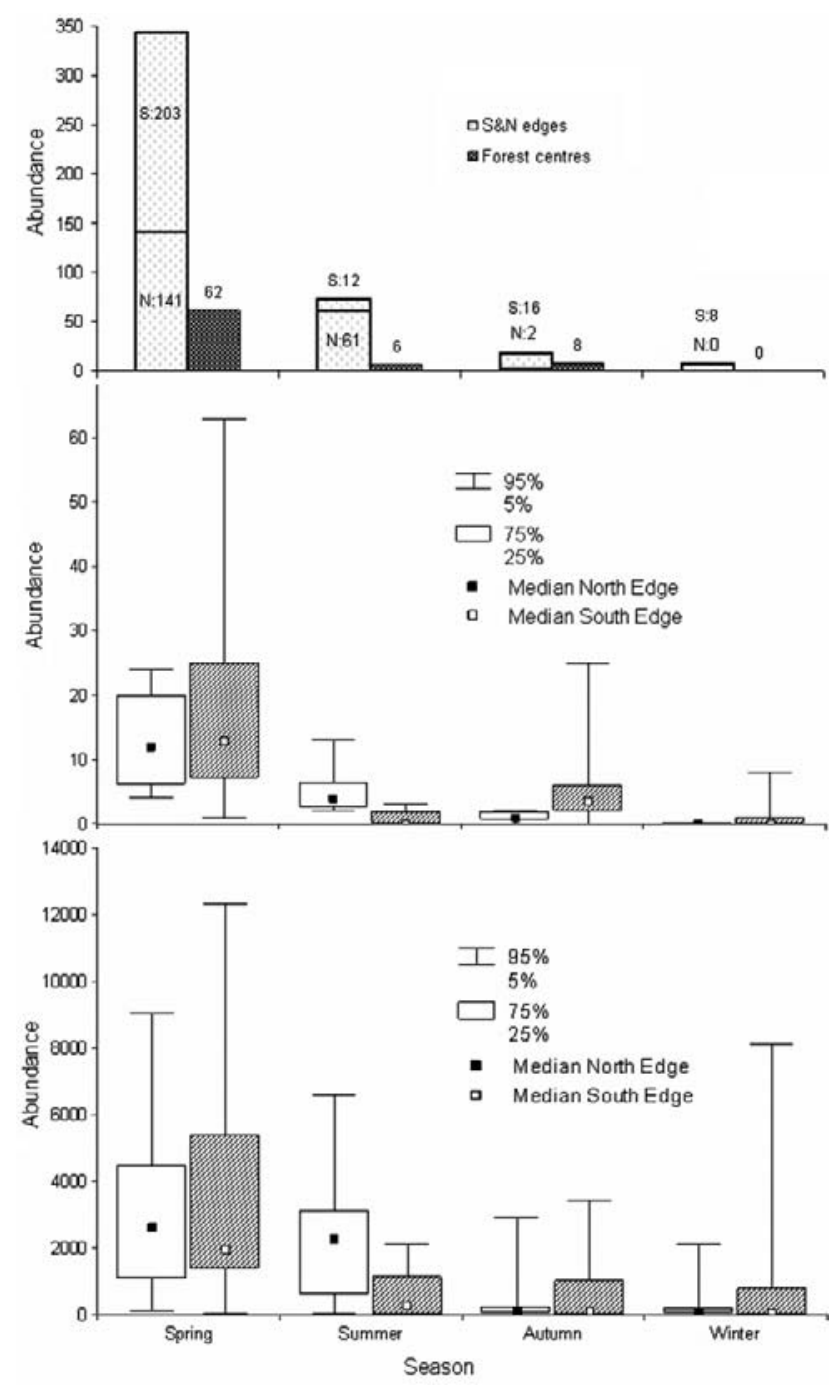

Fig. 1. Abundances of Episyrphus balteatus and flowers for each season: Total E. balteatus abundance in south- plus northfacing edges and in forest centres (top). Average E. balteatus abundance in south- and in north-facing edges (middle). Total flower abundance in south- and in north-facing edges (bottom). 
TABLE 4. Correlation between flower and E. balteatus abundances. Correlations are described by the value of the Spearman's R and by the degree of significance of the correlation (n.s.: non-significant; $*$ : $<<0.05 ; * *: \mathrm{p}<0.01 ; *^{* *}: \mathrm{p}<0.001$ ).

\begin{tabular}{lccc}
\hline Season & Total flower ab. & Edge flower ab. & Field flower ab. \\
\hline spring & $+0.3898^{* *}$ & $-0.3943 * *$ & $+0.5235 * * *$ \\
summer & $+0.5107^{* *}$ & $+0.5991^{* *}$ & n.s. \\
autumn & n.s. & $-0.3081 *$ & n.s. \\
winter & $+0.35 *$ & n.s. & $+0.3919 * *$ \\
\hline
\end{tabular}

much more frequently found along north-facing edges ( $\mathrm{p}$ $=0.0001)$. In autumn, the distribution was inverted, with more individuals found along south-facing edges $(\mathrm{p}=$ $0.004)$, and this distribution was strengthened in winter with an exclusive abundance along south-facing edges ( $p$ $=0.007$ ).

Total flower abundance obviously also varied through the year and showed overall a similar trend (Fig. 1). In spring, total flower abundance did not differ between north- and south-facing edges $(p=0.9381)$, while in summer more flowers occurred along north edges $(\mathrm{p}=$ 0.004). Both in autumn and winter, total flower abundance appeared to be higher on south- rather than northfacing edges, but nevertheless there were no significant differences ( $\mathrm{p}=0.83$ and $\mathrm{p}=0.50$ respectively).

Correlations between E. balteatus and flower abundances varied in time and space (Table 4). In spring, total flower abundance was well correlated with E. balteatus abundance. Nevertheless, the influence of edge flowers and field flowers were contradictory, with a positive correlation with field-flower and a negative one for edgeflower abundance. In summer, total flower abundance was again positively correlated with E. balteatus abundance, entirely due to edge-flower abundance. In autumn, although total flower abundance was not correlated, a negative correlation was found between edge-flower abundance and that of E. balteatus. In winter, a positive correlation was found between total flower abundance and E. balteatus abundance, due to field flower abundance.

The four automatic recording probes showed a highly significant difference between the two south- and two north-facing edges through the year $(p=0.000$ for both pairs of probes).

\section{Pre-imaginal overwintering stage}

Two of the ten emergence traps provided 6 males and 14 females of $E$. balteatus adults (5 in a south-facing emergence trap and 15 in a north-facing one). The specimens emerged mainly in May, but ranged from the end of April to the beginning of June.

\section{DISCUSSION}

Interpreting these results from the agronomic point of view of biological control of aphids, for which early arrival of a natural enemy is required in spring (Honěk, 1983; Tenhumberg \& Poehling, 1995; Corbett, 1998), leads first to a focus on parameters which favour overwintering E. balteatus females. In winter, flowers in fields (there are virtually no flowers along the forest edges) may explain in part the presence of $E$. balteatus females along south-facing edges. Nevertheless, probably more important is physical protection against wind (Lewis, 1965) and rain, and occurrence of warmer temperatures, especially on sunny days (as the four automatic probes significantly proved).

In the following spring, this feature seems still to have a detectable influence, since the highest numbers of $E$. balteatus recorded from the forests occurred in those with a long south-facing edge, while at that time there is no longer any significant difference between south- and north-facing edges (and many fewer individuals in forest centres). Moreover, negative or positive correlations between abundances of flowers (total, edge and field flowers) and E. balteatus prove that if south-facing edges favour populations of $E$. balteatus females in winter, they no longer retain its individuals in spring even if they exhibit concentrations of plants in flower. Indeed, the syrphid could be attracted by flowers in grasslands and CAP fallows, which could also explain the fact that grasslands (plus CAP fallows) in the $2000 \mathrm{~m}$ buffer have in spring a negative contribution to E. balteatus abundance within forest, where they are much less attracted. Actually, Wratten \& Thomas (1990) have shown that syrphids are attracted in spring by uncultivated habitats in the rural landscape. This assumption is supported by higher E. balteatus abundance in edges close to flowering fields (mainly natural grasslands and CAP fallows): E. balteatus could forage in flowering fields and come back to shelter for the night in warmer locations (edges reflect infrared radiation in the night (Robert et al., 1976) or during rainy and windy periods (Lewis, 1965). These grasslands (plus CAP fallows) have, for all categories (i.e. males, females and males plus females), a negative but non-significant influence within $100 \mathrm{~m}$ radius, most probably because they are not sufficiently numerous in this buffer zone, from a statistical point of view.

The fact that overwintering females of E. balteatus could search out sheltered locations quite independently of trophic resources, is strengthened by the significant positive contribution of shrub fallows in the $2000 \mathrm{~m}$ buffer in spring, particularly and quite logically for females. Actually, these shrub fallows are very good shelters in winter since they are composed of scattered thick bushes, most of the time very close to south-facing edges of forests, on more or less south-facing slopes (thus offering suitable shelters under winter conditions). Although they have no flowers in winter, since they essentially consist of perennial grass cover (Arrhenatherum elatius Schübl. \& Martens, Agropyrum repens P.B., Dactylis glomerata L., Festuca spp.) and shrub (Cornus sanguinea L., Ulmus minor L., Prunus spinosa L., Quercus pubescens Wild., Rosa canina L., Juniperus communis L.) patches, their local shelter effect in winter is still perceptible in spring at a wide landscape level. In spring, their few flowers (e.g. Rosa canina) or even their lack of flowers can no longer retain E. balteatus and shrub fallows lead to a low population of this 
syrphid in a forest when they are numerous around it (within the $100 \mathrm{~m}$ buffer).

Surface area and edge length are the most positive and significant factors influencing E. balteatus distribution and abundance in forests in spring, for both sexes. Edge length might have an influence mainly through the lengths of south- and north-facing edges, because the former is much used by overwintering females and the former plus the latter potentially shelter E. balteatus individuals overwintering as developmental stages in the edge vegetation. It is so clear now that this beneficial syrphid has a third way for overwintering, at least in south-west of France, namely as a pre-imaginal stage. This fact may explain the increase of $E$. balteatus numbers in early spring in this region, when a potential northwards migration may not have yet happened (J.P. Sarthou, unpubl.). Thus both pre-imaginal individuals and overwintering adult females may play a key role in early spring in the biological control of aphids in winter wheat, while in northern Europe it is apparent that efficient control of aphids essentially depends on northwardly migrating individuals (Ankersmit et al., 1986; Groeger, 1993). Surface area cannot have any strong intrinsic effect, neither through the inner structure of the forest (as seen above) nor through the higher diversity of the surrounding crop mosaic (since there was not a single significant correlation with wide landscape-level parameters). Surface area acts extrinsically via the asymptotic adjustment of trap numbers to forest surface area.

Given the influence of the surface area on E. balteatus abundance (as seen above) and the high significant correlation between this abundance and the ratio S/EL, this latter is probably influential mainly because, in this study region, the most compact forests are also the largest.

Winter crops, whatever the buffer radius, have a nonsignificance influence but come just after the leastsignificant influencing factor. This is probably the result of the very low aphid infestations on winter cereals during the year of the study (as confirmed by official records of plant protection surveys).

In summer, this syrphid species clearly prefers to live along north-facing edges of forest, where flowers are also present in significantly larger numbers. Forest centres have no flowers and are thus even less visited than southfacing edges. In open ground habitats (crops, fallows) $E$. balteatus clearly seems to be replaced during this dry season by Sphaerophoria scripta (L.), another aphidophagous beneficial syrphid (J.P. Sarthou, unpubl.).

Finally, in autumn the non-significant or low negatively significant correlations between E. balteatus and flowers show that E. balteatus focuses mainly on locations providing physical shelter while day length and temperatures decrease. This interpretation is strengthened by a wide landscape-level observation: the S/EL parameter, which reflects forest shape as seen above, has the second highest significant influence on E. balteatus in forests. Hence this species is attracted in autumn by quite large forest patches with which long south-facing edges are well correlated, independently of the distribution of flowers. These latter are evenly distributed in suitable places within the landscape and might be much less urgently sought by the syrphid than in spring, because of the autumnal cessation of reproduction.

Episyrphus balteatus distribution and abundance prove to be dependent both on local and wide landscape parameters, peculiar to forests and the crop mosaic respectively, which act at different periods through the year and sometimes with a lasting effect.

It remains necessary to validate the hypothesis that winter shelter is provided by shrub fallows and to explore the distance up to which overwintering $E$. balteatus females are able to fly and feed on flowers in surrounding fields. The places where pre-imaginal stages preferentially overwinter also require investigation.

AKNOWLEDGEMENTS. We would like to thank all the people involved in the field surveys: L. Burnel, N. Dauder, E. Delé, L. Denhez, C. Doumenq, E. Gasparotto, M.L. Lafargue, M.H. Monteil, V. Moulin, M. Perroy, L. Raison, C. Rocher and V. Sarthou. Farmers and other private woodland owners and the Office National des Forets are warmly thanked for kindly allowing us to trap in their woods. We are also indebted to M.C.D. Speight for valuable comments on an early draft of the manuscript, for improving the English and above all for his thought that Episyrphus balteatus could also overwinter at a pre-imaginal stage, an idea we then followed and tested.

\section{REFERENCES}

Ankersmit G.W., Dijkman H., Keuning N.J., Mertens H., Sins A. \& TACOMA H.M. 1986: Episyrphus balteatus as a predator of the aphid Sitobion avenae on winter wheat. Entomol. Exp. Appl. 42: 271-277.

Aubert J., Aubert J.J. \& Goeldlin P. 1976: Douze ans de captures systématiques de Syrphides (Diptères) au col de Bretolet (Alpes valaisannes). Bull. Soc. Entomol. Suisse 49: 115-142.

Balent G. \& Courtiade B. 1992: Modelling bird communities / landscape patterns relationships in a rural area of SouthWestern France. Landsc. Ecol. 6: 195-211.

CoRBetT A. 1998: The importance of movements in the response of natural enemies to habitat manipulation. In Pickett C.H. \& Bugg R.L.: Enhancing Biological Control. University of California Press, Los Angeles, $422 \mathrm{pp}$.

Friden H., Koivula K. \& Wold S. 1994: Simca for Windows. UMETRI AB.

Groeger U. 1993: Investigations on the regulation of cereal aphid populations under the influence of the structure of agroecosystems. Agrarökologie 6, 169 pp. [in German]

GurR M., Wratten S.D. \& Altieri M.A. 2004: Ecological Engineering for Pest Management: Advances in Habitat Manipulation for Arthropods. CAB International, Wallingford, $256 \mathrm{p}$.

Guyon J.P., Bessières F., Faingnaert O. \& Bois J.C. 1996: Evolution des formations boisées sur le territoire de deux communes du canton d'Aurignac (Haute-Garonne) de 1942 à 1992. In Balent G. (ed.): La Forêt Paysanne dans l'Espace Rural. Biodiversité, Paysages, Produits. INRA, Paris, p. 268.

HoNĚK A. 1983: Factors affecting the distribution of larvae of aphid predators (Col., Coccinellidae and Dipt., Syrphidae) in cereal stands. Z. Angew. Entomol. 95: 336-345.

KAREIVA P. 1987: Habitat fragmentation and the stability of predator-prey interactions. Nature 326: 388-390.

Kruess A. \& TscharntKe T. 1994: Habitat fragmentation, species loss and biological control. Science 264: 1581-1584. 
Landis D.A., Wratten S.D. \& GurR G.M. 2000: Habitat management to conserve natural enemies of arthropod pests in agriculture. Annu. Rev. Entomol. 45: 175-201.

LEWIS T. 1965: The effects of an artificial wind break on the aerial distribution of flying insects. Ann. Appl. Biol. 55: 503-512.

Lyon J.P. 1967: Déplacements et migrations chez les Syrphidae. Ann. Epiphyties 18(1): 117-118.

Mac Arthur R.H. \& WiLson E.O. 1967: The Theory of Island Biogeography. Princetown University Press, Princetown, 224 pp.

Marino P.C. \& LANDIS D.A. 1996: Effect of landscape structure on parasitoid diversity and parasitism in agroecosystems. Ecol. Applic. 6: 276-284.

Molthan J. 1990: Composition, community structure and seasonal abundance of hoverflies (Dipt., Syrphidae) on field margin biotopes in the Hersian Ried. Mitt. Dt. Ges. Allg. Angew. Entomol. 7: 368-379.

Naes T. \& Martens H. 1989: Multivariate Calibration. John Wiley, New York, 438 pp.

Nentwig W. 1988: Augmentation of beneficial arthropods by strip management. I - Succession of predaceous arthropods and long-term change in the ratio of phytophagous and predacious arthropods in a meadow. Oecologia 76: 597-606.

Ouin A., Sarthou J.P., Bouyjou B., Deconchat M., Lacombe J.P. \& MonteIL C. (in press): The species-area relationship in the hoverfly (Diptera, Syrphidae) communities of forest fragments in southern France. Ecography

PoEHLING H.-M. 1988: Auftreten von Syrphiden- und Coccinellidenlarven in Winterweizen von 1984-1987 in Relation zur Abundanz von Getreideblattläusen. Mitt. Dt. Ges. Allg. Angew. Entomol. 6: 248-254.

Robert Y., Brunel E., Malet P. \& Bautrais P. 1976: Distribution spatiale des pucerons ailés et de diptères dans une parcelle de bocage, en fonction des modifications climatiques provoquées par les haies. In INRA, CNRS, ENSAT and Rennes U.D. (eds): Les Bocages, Histoires, Economie, Ecologie. pp. 427-435.

Rojo S., Gilbert F., Marcos-Garcia M.A., Nieto J.M. \& Mier M.P. 2003: A World Review of Predatory Hoverflies (Diptera,
Syrphidae: Syrphinae) and Their Prey. CIBIO Ediciones, Alicante, $320 \mathrm{pp}$.

Russell E.P. 1989: Enemies hypothesis: A review of the effect of vegetational diversity on predatory insects and parasitoids. Environ. Entomol. 18: 590-599.

Sarthou J.P. 1996: Contribution à l'Etude Systématique, Biogéographique et Agroécocénotique des Syrphidés (Insecta, Diptera) du Sud-Ouest de la France. PhD. thesis, INP Toulouse, $251 \mathrm{pp}$.

SCHNEIDER F. 1948: Beitrag zur Kenntnis der Generationsverhältnisse und Diapause räuberischen Schwebfliegen (Syrphidae, Diptera). Mitt. Schweiz. Entomol. Ges. 21: 249-285.

Speight M.C.D. 2003: Species account of European Syrphidae (Diptera) 2003. In Speight M.C.D., Castella E., Sarthou J.-P. \& Ball S. (eds): Syrph the Net, the Database of European Syrphidae. Vol. 39. Syrph the Net publications, Dublin, 209 pp.

Speight M.C.D., Castella E. \& Obrdlik P. 2003: Macrohabitats preferences of European Syrphidae (Diptera). In Speight M.C.D., Castella E., Sarthou J.-P. \& Ball S. (eds): Syrph the Net, the Database of European Syrphidae. Vol. 40. Syrph the Net publications, Dublin, $552 \mathrm{pp}$.

Tenenhaus M. 1998: La Régression PLS, Théorie et Pratique. Technip, Paris, 254 pp.

Tenhumberg B. \& Poenling H.M. 1995: Syrphids as natural enemies of cereal aphids in Germany: aspects of their biology and efficacy in different years and regions. Agric. Ecosyst. Environ. 52(1): 39-43.

Thies C. \& TscharntKe T. 1999: Landscape structure and biological control in agroecosystems. Science 285: 893-895.

Thomas M.B., Wratten S.D. \& Sotherton N.W. 1992: Creation of "Island" habitats in farmland to manipulate populations of beneficial arthropods: predator densities and species composition. J. Appl. Ecol. 29: 524-531.

TSCHARNTKE T. \& KRUESS A. 1999: Habitat fragmentation and biological control. In Hawkins B.A. \& Cornell H.V. (eds): Theoretical Approaches to Biological Control. Cambridge University Press, Cambridge, pp. 190-205.

Wratten S.D. \& Thomas M.B. 1990: Environmental manipulation for the encouragement of natural enemies of pests. Monograph of British Crop Protection Council No. 45. pp. 87-92.

Received September 27, 2004; revised and accepted April 13, 2005 